\title{
ARTIKELEN
}

\section{Detentie en autonomie}

\section{Over de psychologische basis van vrijwillig handelen en zelfredzaamheid*}

Josi Driessen, Renske Potgieter, Anja Dirkzwager, Joke Harte \& Henk Aarts**

\section{Inleiding}

Crimineel gedrag is schadelijk voor de samenleving. Naast financiële schade veroorzaakt het immateriële schade, zoals gevoelens van angst en onveiligheid. ${ }^{1}$ Straffen worden beschouwd als een middel om de criminaliteit onder controle te houden en terug te dringen. In Nederland is detentie de zwaarste straf die opgelegd kan worden. Net als andere straffen heeft het opleggen van detentie tot doel de rechtsorde te herstellen en de veiligheid in de samenleving te verhogen door (nieuwe) criminaliteit te voorkomen. ${ }^{2}$ Naast deze beoogde doelen kan detentie ook andere onbedoelde gevolgen hebben. Inherent aan detentie is dat er sprake is van vergaande beperkingen van de vrijheid. Vrijheidsbeperkende maatregelen kunnen ingrijpende consequenties hebben voor de autonomie van gedetineerden. Detentie heeft doorgaans een grote impact op de handelingsvrijheid, waardoor gedetineerden niet meer zelf kunnen bepalen hoe ze hun dagelijks leven inrichten en organiseren. ${ }^{3}$ Persoonlijke autonomie speelt echter een centrale rol in menselijk handelen. Omstandigheden die autonomie bevorderen dragen positief bij aan zelfstandig

* Deze publicatie maakt deel uit van het project 'Prison and Autonomy: Implicit psychological markers of the sense of agency in detention' (406.18.GO.047) van het programma 'NWO Open Competitie SGW', dat is gefinancierd door de Nederlandse Organisatie voor Wetenschappelijk Onderzoek (NWO).

** Dr. J.M.A. Driessen is onderzoeker (postdoc) bij de afdeling Social Health \& Organisational Psychology aan de Universiteit Utrecht. R.H. Potgieter, MSc is projectsecretaris bij het RIEC Amsterdam-Amstelland. Dr. A.J.E. Dirkzwager is senior onderzoeker bij het Nederlands Studiecentrum voor Criminaliteit en Rechtshandhaving. Prof. dr. J.M. Harte is hoogleraar bij de afdeling Strafrecht en Criminologie van de Vrije Universiteit Amsterdam en lid van de redactie van PROCES. Prof. dr. H. Aarts is hoogleraar bij de afdeling Social Health \& Organisational Psychology van de Universiteit Utrecht.

1 R. Choenni, S.W. van den Braak \& P.F.M. Platenburg, Criminaliteit en rechtshandhaving 2018. Ontwikkelingen en samenhangen, Den Haag: Wetenschappelijk Onderzoek- en Documentatiecentrum 2019.

2 L. van Noije \& K. Wittebrood, Overlast en verloedering ontsleuteld. Veronderstelde en werkelijke effecten van het Actieplan overlast en verloedering, Sociaal Cultureel Planbureau, 2009.

3 J. Woodall, R. Dixey \& J. South, 'Control and choice in English prisons: developing health-promoting prisons', Health Promotion International 2014, 29, p. 474-482. 
functioneren en sociaal gedrag, terwijl omstandigheden die autonomie beperken hierop een negatieve invloed lijken te hebben. ${ }^{4}$

Verschillende studies suggereren dat voornoemde inperking van de autonomie tijdens de detentie een succesvolle terugkeer in de samenleving belemmert en het risico op recidive mogelijk zelfs verhoogt. Zo geven recente inzichten aan dat detentie de zelfredzaamheid van gedetineerden vermindert en daarmee het vermogen ondermijnt om zelfstandig dagelijkse handelingen te verrichten en hierbij eventueel de benodigde hulp en ondersteuning te organiseren., ${ }^{5}$ Op deze manier kunnen beperkingen in handelingsvrijheid onbedoelde negatieve gevolgen hebben voor de zelfredzaamheid van gedetineerden.

In dit artikel verkennen wij wat in de wetenschappelijke literatuur bekend is over hoe vrijheidsbeperkingen het psychologische proces beïnvloeden dat ten grondslag ligt aan zelfredzaamheid. In de context van detentie bouwen we hierbij voort op het deprivatiemodel van Sykes, dat stelt dat de effecten van detentie op de terugkeer in de samenleving zijn geworteld in het ontnemen van vrijheid en andere aan detentie inherente omstandigheden. ${ }^{7}$ Door de gebieden van criminologie en sociale neurowetenschappen te verbinden, en zodoende te bekijken hoe de beperkingen van autonomie de neurocognitieve basis van vrijwillig handelen verstoren en daarmee de zelfredzaamheid van (ex-)gedetineerden ondermijnen, beogen we meer inzicht te geven in de relatie tussen detentie, autonomie en zelfredzaamheid.

In het navolgende bespreken we eerst de betekenis van autonomie in de moderne samenleving. Daarna gaan we in op de relatie tussen autonomie en de psychologische basis van het gevoel uit eigen beweging en vrijwillig te handelen. We kijken vervolgens naar de rol van detentie als straf, de daarbij aanwezige beperkingen in persoonlijke autonomie en de mogelijke gevolgen voor de zelfredzaamheid van gedetineerden. Aansluitend bespreken we wat er tot op heden bekend is in de literatuur over de relatie tussen detentie, autonomie en de ervaring van vrijwillig handelen. We sluiten dit artikel af met een aantal suggesties voor toekomstig onderzoek. De belangrijkste concepten en hun onderlinge (voorspelde) relaties die worden besproken in dit artikel zijn weergegeven in figuur 1.

4 R.M. Ryan \& E.L. Deci, 'Self-determination theory and the facilitation of intrinsic motivation, social development, and well-being', American Psychologist 2000, 1, p. 68-78. M. Cardol, B.D. Jong \& C.D. Ward, 'On autonomy and participation in rehabilitation', Disability and Rehabilitation 2002, 18, p. 970-974.

5 B.J. de Jong, P.J.H. Willems \& A.E. van Burik, Evaluatie pilots zelfredzaamheid gedetineerden, Woerden: Van Montfoort 2015.

$6 \quad$ B.J. de Jong, P.J.H. Willems \& L.D.R. Torregrosa, Zelfredzaamheid in detentie, 2016.

7 G.M. Sykes, The Pains of Imprisonment, Princeton, NJ: Princeton University Press 1958. 
Figuur 1 Overzicht van de kernconcepten en hun onderlinge relaties

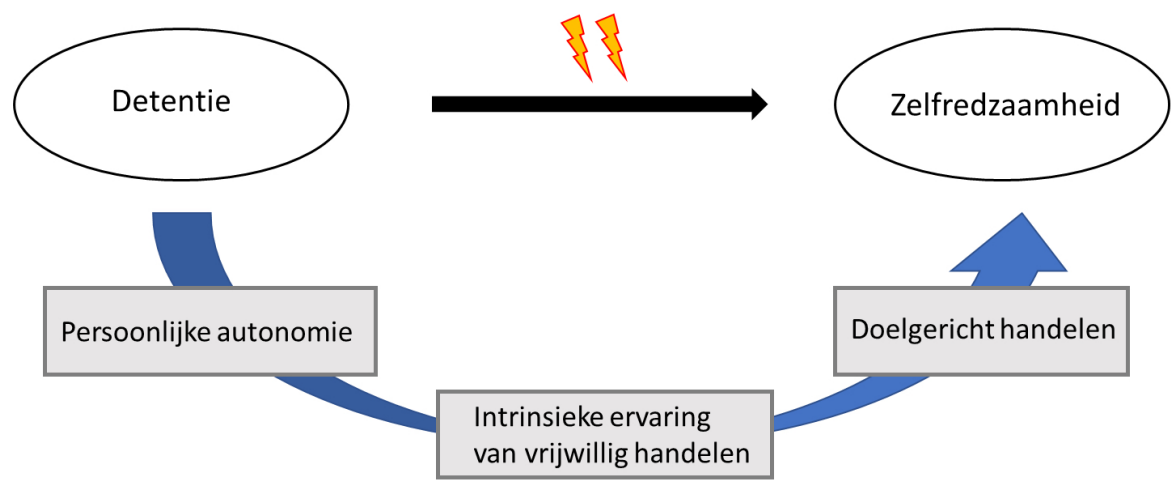

De blauwe pijl in figuur 1 demonstreert de psychologische route waarlangs detentie mogelijk een negatief effect heeft op de zelfredzaamheid van gedetineerden. De kernconcepten worden hierna verder besproken.

\section{De betekenis van autonomie in de moderne samenleving}

Autonomie is een centraal onderdeel van een democratische samenleving. De term autonomie heeft verschillende betekenissen in zowel verschillende disciplines als door de tijd heen. Traditioneel is het autonomieconcept sterk geworteld in de filosofie van menselijk gedrag. Vroege filosofen, zoals Jeremy Bentham en John Stuart Mill, zagen autonomie in termen van onvoorwaardelijke keuzevrijheid..${ }^{8,9}$ Voor Mill betekent autonomie volledige individuele vrijheid die alleen mag worden beperkt om anderen te beschermen. Moderne geleerden in de filosofie, recht en ethiek zijn het er in het algemeen over eens dat autonomie verwijst naar het vermogen van een individu tot zelfbestuur. Over de precieze definitie is echter veel discussie. In dat licht valt de neokantiaanse definitie van autonomie op, volgens welke autonomie sterke noties kan bevatten over het juiste doen, ofwel morele autonomie. ${ }^{10}$ Binnen het onderzoek naar menselijke cognitie en gedrag heeft autonomie betrekking op de vraag of een persoon zelf de mogelijkheid heeft om te handelen en be- 
slissingen te nemen om eigen doelen te bereiken. ${ }^{11,12,13}$ Deze benadering van autonomie bevat een duidelijke persoonlijke component. ${ }^{14,15}$ Persoonlijke autonomie houdt in dat een persoon de vrijheid heeft om te handelen in een omgeving die ook daadwerkelijk de gelegenheid biedt om zelf te bepalen welke handeling waar, wanneer en hoe wordt uitgevoerd. Moderne samenlevingen worden gekenmerkt door institutionele contexten, die ongedwongen handelen mogelijk maken, maar die ook juridische en morele beperkingen hebben die meer dwingend zijn. Zo kan een persoon bijvoorbeeld vrij zijn om met de auto naar het werk te reizen, maar wordt er wel verwacht dat hij of zij de verkeersregels volgt. Deze mix van zelfgekozen en opgelegd gedrag benadrukt de begrenzing van persoonlijke autonomie.

Iedereen die deze grenzen herkent en over het vermogen beschikt om zelfstandig doelen te stellen en ze na te streven, bezit persoonlijke autonomie om binnen de institutionele context zijn eigen leven te organiseren. Bij personen die in detentie verblijven, zijn deze grenzen zodanig dat het vermogen om zelfstandig te handelen ernstig is beperkt. Zij mogen immers niet zelf bepalen hoe ze hun dagelijks leven inrichten en organiseren. In deze bijdrage hanteren we de term persoonlijke autonomie om aan te geven dat zelfstandig functioneren afhankelijk is van de persoonlijke situatie waarin vrijheidsbeperkingen al dan niet zijn opgelegd.

\section{Persoonlijke autonomie en de intrinsieke ervaring van vrijwillig handelen}

Persoonlijke autonomie wordt vaak in verband gebracht met zelfredzaamheid. In de huidige samenleving is een persoon doorgaans zelf verantwoordelijk voor (het regelen van) adequate zorg, sociale integratie, financiën en werk. Cruciaal is echter dat persoonlijke autonomie sterk samenhangt met een diepgeworteld gevoel dat men uit eigen beweging handelt en zelf de actor is van het eigen gedrag en de gevolgen daarvan. Dit gevoel wordt ook wel de intrinsieke ervaring van vrijwillig handelen genoemd (sense of agency in het Engels).

Vanuit de experimentele psychologie is aangetoond dat de intrinsieke ervaring van vrijwillig handelen essentieel is voor doelgericht handelen. ${ }^{16,17}$ Aangezien mensen doorgaans handelen in een sociale context speelt hierbij ook het oordelen over eigen verantwoordelijkheid een belangrijke rol. ${ }^{18,19}$ Mensen die hun eigen gedrag

11 H. Aarts \& A. Elliot, Goal-directed behavior, New York: Psychology Press 2012.

12 R.M. Ryan \& E.L. Deci, 'Self-regulation and the problem of human autonomy: Does psychology need choice, self-determination, and will?', Journal of Personality 2006, 74, p. 1557-1586.

13 A. Vugts e.a., 'How autonomy is understood in discussions on the ethics of nudging', Behavioural Public Policy 2020, 1, p. 108-123.

14 G. Dworkin, The Theory and Practice of Autonomy, Cambridge: Cambridge University Press 1988.

15 H.G. Frankfurt, The importance of what we care about: Philosophical essays, Cambridge: Cambridge University Press 1988.

16 A. Bandura \& R. H. Walters, Social learning theory, Englewood Cliffs, NJ: Prentice-hall 1977.

17 H. Aarts, R. Custers \& D.M. Wegner, 'On the inference of personal authorship: Enhancing experienced agency by priming effect information', Consciousness and Cognition 2005, 14, p. 439-458.

18 T.G. Damen e.a., 'Put your plan into action: The influence of action plans on agency and responsibility', Journal of Personality and Social Psychology 2015, 108, p. 850-866.

19 G. Moretto, E. Walsh \& P. Haggard, 'Experience of agency and sense of responsibility', Consciousness and Cognition 2011, 20, p. 1847-1854. 
niet als vrijwillig ervaren, zijn minder snel gemotiveerd hun eigen doelen te stellen, plannen te maken en deze uit te voeren, en te herkennen wanneer hun gedrag voldoet aan sociale normen en waarden. Vanuit dit perspectief is zelfredzaamheid voor een belangrijk deel afhankelijk van de intrinsieke ervaring van vrijwillig handelen. ${ }^{20} \mathrm{Bij}$ (ex-)gedetineerden kan een verstoring in de intrinsieke ervaring van vrijwillig handelen en de gevolgen daarvan voor de zelfredzaamheid het resocialisatieproces ernstig belemmeren.

\subsection{Hoe krijgen we inzicht in iemands autonomie en de intrinsieke ervaring van vrijwillig handelen?}

Menselijke reacties op beperkingen in autonomie worden doorgaans vastgesteld via vragenlijsten. ${ }^{21,22}$ Hierbij wordt aan mensen bijvoorbeeld gevraagd om zich een situatie uit het verleden voor te stellen waarin hun autonomie werd beperkt en worden er vervolgens vragen gesteld over wat ze van deze situatie vonden en hoe ze zich voelden. Dergelijke rapportages kunnen een goed beeld geven van hoe mensen over autonomie denken, maar zijn minder geschikt om inzicht te krijgen in de intrinsieke ervaring van vrijwillig handelen onder beperkingen van autonomie. Een belangrijke reden hiervoor is dat uit onderzoek blijkt dat mensen vaak de neiging hebben om onnauwkeurige voorspellingen en oordelen over zichzelf te maken, dat antwoorden op dergelijke vragen gevoelig zijn voor fouten en vertekeningen, en dat sociaal wenselijke antwoorden niet zijn uit te sluiten. ${ }^{23,24,25,26,27}$ Zelfrapportages over autonomie zijn daardoor minder geschikt om de intrinsieke ervaring van vrijwillig handelen vast te stellen.

Recentelijk heeft neurocognitief onderzoek een andere, meer geschikte benadering gevonden om de intrinsieke ervaring van vrijwillig handelen vast te stellen. In plaats van rechtstreeks naar een mening te vragen wordt gekeken hoe het brein en onze waarneming reageren op autonomiebeperkingen van ons gedrag. ${ }^{28}$ De intrinsieke ervaring van vrijwillig handelen is het directe resultaat van de wijze waarop

20 R.A. Renes \& H. Aarts, "The sense of agency in health and well-being: Understanding the role of the minimal self in action-control', in: D. De Ridder, M. Adriaanse \& K. Fujita (red.), Routledge International Handbook of Self-Control in Health and Well-Being, Londen: Routledge 2017, p. 193-205.

21 J.A. Breaugh, 'The measurement of work autonomy', Human relations 1985, 6, p. 551-570.

22 J.Y. Ng e.a., 'Self-determination theory applied to health contexts: A meta-analysis', Perspectives on Psychological Science 2012, 4, p. 325-340.

23 D.T. Gilbert e.a., 'Immune neglect: a source of durability bias in affective forecasting', Journal of personality and social psychology 1998, 3, p. 617-638.

24 H. Aarts \& A. Dijksterhuis, 'How often did I do it? Experienced ease of retrieval and frequency estimates of past behavior', Acta Psychologica 1999, 103, p. 77-89.

25 N.M. Bradburn, L.J. Rips \& S.K. Shevell, 'Answering autobiographical questions: The impact of memory and inference on surveys', Science 1987, 236, p. 157-161.

26 R.E. Nisbett \& T.D. Wilson, 'Telling more than we can know: verbal reports on mental processes', Psychological Review 1977, 84, p. 231-259.

27 D.L. Paulhus, 'Socially Desirable Responding: The Evolution of a Construct', in: H.I. Braun, D.N. Jackson \& D.E. Wiley (red.), The Role of Constructs in Psychological and Educational Measurement 2001, Mahwah, NJ: Lawrence Erlbaum Associates, p. 49-69.

28 P. Haggard, 'Sense of agency in the human brain', Nature Reviews Neuroscience 2017, 4, p. 196-208. 
ons brein op de gevolgen van onze vrijwillige handeling anticipeert. ${ }^{29}$, 30, 31, 32 Deze anticipatie door het brein is heel nauwkeurig, waardoor we precies weten wanneer de gevolgen van onze vrijwillige handelingen optreden. We zien of horen dus als het ware wat er gaat gebeuren voordat we handelen. Een vrijwillige handeling wordt daardoor ervaren als een coherent geheel dat vloeiend verloopt. Daarnaast zijn we ons eerder bewust van onze acties en hun gevolgen wanneer we handelingen vrijwillig uitvoeren. Zo worden zaken als afslaan op de autosnelweg, iemand blij maken met een compliment of geld overmaken via internet als coherente gebeurtenissen ervaren waar men zich doorgaans bewust van is. Zonder de intrinsieke ervaring van vrijwillig handelen lijkt ons gedrag rommelig, oncontroleerbaar en aan onze aandacht te ontsnappen.

Een van de methoden die wordt ingezet om de intrinsieke ervaring van vrijwillig handelen te meten zijn tijdsinschattingen om te kijken hoe mensen actie en gevolg aan elkaar verbinden. In een dergelijke meting kunnen proefpersonen bijvoorbeeld op een knop drukken met als gevolg dat er een plaatje of geluid wordt gepresenteerd. De proefpersoon wordt dan gevraagd hoelang de tijd tussen het indrukken van de knop en het gevolg ervan duurde. Bij normaal vrijwillig handelen blijken mensen de tijd tussen hun acties en gevolgen korter in te schatten dan in werkelijkheid het geval is. Deze temporele binding tussen acties en gevolgen neemt af wanneer er sprake is van gedwongen handelen. ${ }^{33,34,35,36}$ Een andere methode is elektro-encefalografie (EEG), waarmee de elektrofysiologische reactie op het zien of horen van de gevolgen van gedrag kan worden bestudeerd. Bij deze methode draagt de persoon tijdens de taak een hoofdkap waarin kleine sensoren zijn aangebracht. Deze sensoren kunnen elektrische signalen uit de hersenen opvangen. Op deze manier kan de breinactiviteit voor, tijdens en na het uitvoeren van gedrag bestudeerd worden. Onderzoek laat zien dat de elektrofysiologische reactie op de gevolgen van gedrag minder sterk is wanneer dat gedrag vrijwillig is gekozen. Deze minder sterke reactie, gemeten in het brein, treedt op door de anticipatie op het gevolg

29 S.J. Blakemore, D.M. Wolpert \& C.D. Frith, 'Central cancellation of self-produced tickle sensation', Nature Neuroscience 1995, 7, p. 635-640.

30 J. Moore \& P. Haggard, 'Awareness of action: Inference and prediction', Consciousness and Cognition 2008, 1, p. 136-144.

31 R.A. Renes e.a., 'An exploratory fMRI study into inferences of self-agency', Social Cognitive and Affective Neuroscience 2015, 5, p. 708-712.

32 M. Dogge e.a., 'Cortical information flow during inferences of agency', Frontiers in Human Neuroscience 2014,8 , p. 609-620.

33 Z. Barlas \& S. S. Obhi, 'Freedom, choice, and the sense of agency', Frontiers in Human Neuroscience 2013, 7, p. 514-521.

34 Z. Barlas, W.E. Hockley \& S.S. Obhi, 'Effects of free choice and outcome valence on the sense of agency: evidence from measures of intentional binding and feelings of control', Experimental Brain Research 2018, 1, p. 129-139.

35 E.A. Caspar e.a., 'Coercion changes the sense of agency in the human brain', Current Biology 2016, 5, p. 585-592.

36 E.A. Caspar, A. Cleeremans \& P. Haggard, 'Only giving orders? An experimental study of the sense of agency when giving or receiving commands', PloS One 2018, 9, e0204027. 
na vrijwillig handelen. ${ }^{37,38}$ Verder heeft neurocognitief onderzoek aangetoond dat ervaring van vrijwillig handelen gepaard gaat met activatie in de frontale en pariëtale cortex, gebieden die doorgaans een rol spelen bij het kiezen en monitoren van gedrag en de uitkomsten ervan. ${ }^{39,40}$

Studies met tijdschattingen en elektrofysiologische responsen suggereren dat wanneer mensen persoonlijke autonomie over hun handelen verliezen en worden gedwongen om bepaalde handelingen uit te voeren, de 'normale' intrinsieke ervaring van vrijwillig handelen wordt verstoord. Onderzoek heeft verder aangetoond dat deze verstoring van de intrinsieke ervaring van vrijwillig handelen ook een aantal duidelijke en belangrijke effecten heeft op het functioneren van mensen. Ten eerste verstoort het een belangrijk onderdeel van zelfredzaamheid, namelijk de motivatie om onze eigen doelen te stellen en de uitvoer ervan te plannen. Verder hangt het samen met het nemen van meer risico's, verminderde weerstand tegen sociale druk, meer afstand nemen van eigen gedrag, en verminderde ervaring van verantwoordelijkheid. ${ }^{41,42,43}$ Kortom, beperkingen in de persoonlijke autonomie verstoren de intrinsieke ervaring van vrijwillig handelen, waardoor de zelfredzaamheid wordt belemmerd. Detentie is een voorbeeld van een situatie waarin de persoonlijke autonomie van mensen fors wordt ingeperkt. Gegeven de resultaten uit de hiervoor genoemde studies is het goed mogelijk dat dit van invloed is op de zelfredzaamheid van gedetineerden en de mate waarin zij risicovol gedrag vertonen. De relatie tussen persoonlijke autonomie en de intrinsieke ervaring van vrijwillig handelen kan daarom de sleutel zijn om beter te begrijpen hoe vrijheidsbeperkingen in detentie de zelfredzaamheid kunnen verminderen.

\section{Detentie en persoonlijke autonomie}

Vrijheidsbeperkingen belemmeren justitiabelen om een autonoom leven te leiden. De beperkingen waarmee een justitiabele te maken krijgt, hangen af van de straftoemeting. Er bestaan diverse vrijheidsbeperkende sancties waardoor justitiabelen beperkt worden in hun persoonlijke autonomie, zoals detentie, werk- of taakstraffen en elektronische detentie. Daarnaast kunnen in verschillende situaties vrijheidsbeperkende voorwaarden - zoals een meldplicht, contactverbod en locatieverbod - worden opgelegd aan justitiabelen, al dan niet in het kader van voorwaardelijke of gedeeltelijk voorwaardelijke gevangenisstraffen, voorwaardelij-

37 M. Dogge e.a., 'Exploring the role of motor and non-motor predictive mechanisms in sensory attenuation: Perceptual and neurophysiological findings', Neuropsychologia 2019, 124, p. 216-225.

38 G. Hughes, A. Desantis \& F. Waszak, 'Mechanisms of intentional binding and sensory attenuation: The role of temporal prediction, temporal control, identity prediction, and motor prediction', Psychological Bulletin 2013, 1, p. 133-151.

39 Renes e.a. 2015, p. 208-712.

40 Dogge e.a. 2014, p. 609-620.

41 B.M. Fennis \& H. Aarts, 'Revisiting the agentic shift: Weakening personal control increases susceptibility to social influence', European Journal of Social Psychology 2012, 7, p. 824-831.

42 T.G. Damen e.a., 'Re-examining the agentic shift: The sense of agency influences the effectiveness of (self) persuasion', PloS One 2015, 6, e0128635.

43 P. Haggard \& M. Tsakiris, 'The experience of agency: Feelings, judgments, and responsibility', Current Directions in Psychological Science 2019, 4, p. 242-246. 
ke invrijheidstellingen, penitentiaire programma's en schorsingen van voorlopige hechtenis. Deze vrijheidsbeperkende voorwaarden kunnen in combinatie met elektronisch toezicht worden gevorderd. Het moeten melden op vaste tijden, het niet zelf mogen kiezen met wie je contact hebt en je niet overal vrij mogen bewegen zijn allemaal voorbeelden van situaties waarin de persoonlijke autonomie wordt ondermijnd. De vrijheid om zelf te bepalen welke handeling je waar, wanneer en hoe uitvoert, ontbreekt.

In Nederland is de vrijheidsstraf, met $31 \%$ van alle opgelegde sancties in 2018, naast boetes de meest opgelegde straf. ${ }^{44}$ De beperkingen in autonomie zijn het grootst in detentie, waar een streng regime doorgaans de dagelijkse gang van zaken bepaalt. Naast het feit dat gedetineerden niet vrij zijn om te bewegen, moeten ze zich bijvoorbeeld houden aan de vaste tijden om te eten en te luchten en zijn ze beperkt in het contact met hun familie. In Nederland worden gevangenisstraffen dan ook gezien als de zwaarst mogelijke vorm van straf. De vergaande autonomiebeperkingen in detentie worden in het deprivatiemodel van Sykes (1958) beschouwd als een van de 'pains of imprisonment'. ${ }^{45}$ Of zoals Shammas dit samenvat: 'Prisoners may lose the ability to make even the most basic decisions about their daily life, such as when and what food to eat, when and how bodily functions should be taken care of, and when and how to move within the restricted confines of the prison.' ${ }^{46}$

De beperkingen in persoonlijke autonomie waar justitiabelen in detentie mee te maken krijgen, dienen het doel om speciale preventie te bewerkstelligen. De mogelijkheid om strafbare feiten te plegen wordt weggenomen, en de dader wordt hiermee onschadelijk gemaakt gedurende de detentieperiode. Naast deze incapacitatie wordt ook resocialisatie van de dader belangrijk geacht om te voorkomen dat een dader opnieuw terugvalt in crimineel gedrag. Door middel van resocialisatie wordt de positie van de dader in de maatschappij zodanig veranderd dat de kans op recidive zo laag mogelijk wordt. Uit artikel 2 van de Penitentiaire beginselenwet, die expliciet stelt dat de tenuitvoerlegging van de vrijheidsstraf zo veel mogelijk dienstbaar gemaakt wordt aan de voorbereiding van de terugkeer in de maatschappij, blijkt dat naast de opsluiting van de dader het proces van resocialisatie van de gedetineerde al een belangrijke rol zou moeten spelen. De geïntensiveerde samenwerking tussen de Dienst Justitiële Inrichtingen (DJI), reclassering en gemeenten in de afgelopen jaren laat dit ook zien. ${ }^{47}$

Desondanks suggereren verschillende onderzoeken naar de speciaal preventieve werking van straffen dat de gevangenisstraf een succesvolle resocialisatie belemmert. Een mogelijke aanwijzing hiervoor zijn de resultaten van recente overzichtsstudies die een criminogeen effect van gevangenisstraffen ten opzichte van andere 2019.

45 Sykes 1958.

46 V.L. Shammas, 'Pains of imprisonment', in: K.R. Kerley (red.), The Encyclopedia of Corrections, New York: John Wiley \& Sons Inc 2017, p. 14.

47 Ministerie van Justitie \& Veiligheid, Dienst Justitiële Inrichtingen \& 3RO, Bestuurlijk akkoord. Kansen bieden voor re-integratie, 2019. 
straffen op toekomstig crimineel gedrag laten zien. ${ }^{48,49,50}$ Zo suggereert onderzoek naar de levensloopomstandigheden van ex-gedetineerden en hun families dat de gevangenisstraf negatieve effecten heeft op de terugkeer in de samenleving. ${ }^{51}$ Het is in dit verband belangrijk om kennis te hebben over mogelijke veranderingen in intrinsieke ervaring van vrijwillig handelen waarlangs detentie via beperkingen in autonomie resocialisatie bemoeilijkt en tot terugval kan leiden.

\section{Detentie, autonomie en de intrinsieke ervaring van vrijwillig handelen: wat weten we uit eerder onderzoek?}

In het volgende onderdeel zullen we beschrijven wat er op dit moment in de literatuur bekend is over de relatie tussen detentie, autonomie en de ervaring van vrijwillig handelen. De term autonomie heeft in criminologisch onderzoek naar detentie verschillende betekenissen. Onderzoek door bijvoorbeeld Boone, Althoff en Koenraadt beschrijft autonomie als 'de mate waarin aan bewoners de mogelijkheid wordt gelaten zelf keuzes te maken', terwijl Van der Laan en Eichelsheim autonomie definiëren als 'de ervaren mogelijkheid door gedetineerden om het eigen gedrag in de instelling te kunnen bepalen en te kunnen klagen over de (handhaving) van de regels'. ${ }^{52,53}$ Deze twee verschillende werkdefinities geven in feite weer dat autonomie in detentie op, respectievelijk, objectieve en subjectieve wijze kan worden benaderd. Een objectieve benadering refereert aan een situatie die buiten de persoon ligt en betreft de mate waarin feitelijke keuzes ten aanzien van wat, wanneer en hoe men iets wil doen zijn beperkt. ${ }^{54}$ Gedetineerden kunnen bijvoorbeeld slechts beperkt kiezen wat ze eten, wanneer ze eten en hoe ze eten. Ditzelfde geldt voor andere beslissingen over hun dagelijks leven, zoals slapen, bewegen en het onderhouden van sociaal contact. Uit interviews als onderdeel van een pilotstudie naar zelfredzaamheid kwam naar voren dat gedetineerden voor dit soort beslissingen sterk afhankelijk zijn van het regime waarin ze geplaatst zijn en het daarbij behorende rooster. ${ }^{55}$

Het merendeel van het bestaand onderzoek bestudeert de ervaren autonomie in detentie, gemeten met behulp van vragenlijsten en interviews. Nederlands onder-

48 D.S. Nagin, F.T. Cullen \& C.L. Jonson, 'Imprisonment and Reoffending', Crime and Justice 2009, 38, p. $115-200$.

49 C.L. Jonson, The impact of imprisonment on reoffending: A meta-analysis (doctoraalscriptie), Cincinnati: University of Cincinnati 2010.

50 P. Villettaz, G. Gillieron \& M. Killias, 'The Effects on Re-offending of Custodial vs. Non-custodial Sanctions: An Updated Systematic Review of the State of Knowledge', Campbell Systematic Reviews 2015, 11, p. 1-92.

51 A. Dirkzwager, P. Nieuwbeerta \& J. Fiselier, 'Onbedoelde gevolgen van vrijheidsstraffen. Een literatuurstudie’, Tijdschrift voor Criminologie 2009, 51, p. 21-41.

52 M. Boone, M. Althoff \& F. Koenraadt, Het leefklimaat in justitiële inrichtingen, Den Haag: Wetenschappelijk Onderzoek- en Documentatiecentrum 2016, p. 16.

53 A. van der Laan \& V. Eichelsheim, 'Juvenile adaptation to imprisonment: Feelings of safety, autonomy and well-being, and behaviour in prison', European Journal of Criminology 2013, 10, p. 430.

54 S. Sankaran e.a., 'Do I have a say? Using conversational agents to re-imagine human-machine autonomy', in: Proceedings of the 2nd Conference on Conversational User Interfaces 2020, p. 1-3.

55 De Jong, Willems\& Van Burik 2015. 
zoek naar deze subjectieve benadering van autonomie inventariseert de mening van gedetineerden over hun opsluiting en het regime dat hun vrijheid beperkt, en heeft voornamelijk plaatsgevonden binnen studies naar het leefklimaat. Het construct leefklimaat wordt gedefinieerd als 'de aspecten van het onvrijwillig residentieel verblijf in justitiële inrichtingen die van invloed zijn op het welbevinden en/of gedrag van de gedetineerden tijdens en na afloop van het verblijf'. ${ }^{6}$ Autonomie wordt, naast contacten tussen personeel en gedetineerden, contacten met de buitenwereld/familiaire relaties, veiligheid, een zinvolle dagbesteding en fysiek welbevinden, beschouwd als een leefklimaatfactor. Hierbij wordt verondersteld dat autonomie een directe positieve invloed heeft op het gedrag en de beleving van het gedwongen verblijf van een gedetineerde.

Onderzoek naar het leefklimaat in alle Nederlandse gevangenissen laat zien dat gedetineerden in strengere regimes negatiever zijn over hun autonomie dan gedetineerden in minder strenge regimes. ${ }^{57}$ De negatieve waardering van strenge detentieregimes kan beïnvloed worden door verschillende factoren, waaronder het contact tussen personeel en gedetineerde en de kwaliteit en kwantiteit van de dagelijkse activiteiten. ${ }^{58}$ Zo blijkt dat georganiseerde activiteiten en de aanwezigheid van personeel tijdens deze activiteiten het welzijn en het gevoel van veiligheid positief kunnen beïnvloeden. Bovendien suggereert recent Nederlands onderzoek dat een minder streng detentieregime een gunstig effect heeft op de agressiviteit van gedetineerden tijdens detentie. ${ }^{59}$ Verder laat buitenlands onderzoek zien dat het toelaten van autonomie - bijvoorbeeld door gedetineerden de keuze te geven tussen verschillende vrijetijdsbestedingen of ze zelf te laten kiezen wanneer ze telefoneren - de ervaren autonomie en de kwaliteit van leven van gedetineerden in detentie kan bevorderen. ${ }^{60}$

Uit het vorenstaande blijkt dat we een redelijk beeld hebben van wat gedetineerden vinden van hun opsluiting en wat het met hen doet. Onderzoek naar de rol van intrinsieke ervaring van vrijwillig handelen binnen de detentiecontext is echter zeer beperkt. Enig empirisch inzicht in de relatie tussen detentie, autonomie en de ervaring van vrijwillig handelen komt uit recent kwalitatief onderzoek. In een interviewstudie onder Britse gedetineerden gaf een deel aan geen keuzevrijheid te ervaren, en dat het strikte gevangenisregime dat de dagelijkse activiteiten beheerst hen ertoe dwingt om persoonlijke controle op te geven en zich te conformeren aan het regime. ${ }^{61}$ Een Amerikaanse studie onderzocht desistance, het proces van stoppen met criminaliteit, onder veroordeelden met een levenslange gevangenisstraf die alsnog vrij waren gekomen. Uit diepte-interviews kwam naar voren dat er veel waarde werd gehecht aan agency ofwel, volgens de definitie van de auteurs, het vermogen om onafhankelijk te handelen en eigen keuzes te maken binnen de soci-

56 Boone, Althoff \& Koenraadt 2016, p. 16.

57 E.F. van Ginneken e.a., 'The Life in Custody Study: The quality of prison life in Dutch prison regimes', Journal of Criminological Research, Policy and Practice 2018, 4, p. 253-268.

58 Van der Laan \& Eichelsheim 2013, p. 424-443.

59 B. Vollaard, M. Knoef \& T. van Dijk, Het effect van een alternatief detentieregime op gedrag en gezondheid van gedetineerden. Een experiment in een penitentiaire inrichting, Tilburg: Tilburg University 2019.

60 J. van der Kaap-Deeder e.a., 'Choosing when choices are limited: The role of perceived afforded choice and autonomy in prisoners' well-being', Law and Human Behavior 2017, 6, p. 567-578.

61 Woodall, Dixey \& South 2014, p. 474-482. 
ale structuur. ${ }^{62}$ De meerderheid van de levenslang gestraften die vrij waren gekomen en opnieuw recidiveerden deden dit uit een gebrek aan agency, waardoor ruimte kwam voor impulsiviteit en een verminderd inschattingsvermogen van gevolgen van handelen. Deze observaties geven aanleiding om te veronderstellen dat langdurige detentie de intrinsieke ervaring van vrijwillig handelen kan verminderen en daarmee de zelfredzaamheid kan beperken, waardoor de kans op een succesvolle terugkeer in de samenleving kleiner wordt.

\section{Discussie en suggesties voor toekomstig onderzoek}

Met dit inleidende artikel is een eerste poging ondernomen om op conceptuele wijze de relatie te leggen tussen beperkingen in persoonlijke autonomie, de psychologische basis van vrijwillig handelen en de zelfredzaamheid onder (ex-)gedetineerden. De relatie tussen persoonlijke autonomie en de intrinsieke ervaring van vrijwillig handelen krijgt recentelijk meer aandacht vanwege het fundamentele belang ervan in doelgericht handelen en het besef van verantwoordelijkheid voor eigen gedrag. Sterke ondermijning van persoonlijke autonomie zou als zodanig zelfstandig functioneren en sociaal gedrag kunnen verstoren. Inperking van de persoonlijke autonomie is inherent aan de detentiesituatie waarbij gedetineerden zich moeten conformeren aan het heersende regime. Onderzoek naar de intrinsieke ervaring van vrijwillig handelen zou daarom kunnen helpen om beter te begrijpen hoe vrijheidsbeperkingen in detentie de zelfredzaamheid zouden kunnen verminderen.

Onderzoek op basis van vragenlijsten en interviews kan een goed beeld geven van hoe mensen over autonomie denken, maar is minder geschikt om inzicht te krijgen in de intrinsieke ervaring van vrijwillig handelen onder beperkingen van autonomie. Het verrichten van onderzoek naar de intrinsieke ervaring van vrijwillig handelen in de context van detentie vraagt daarom om een andere benadering. De onderzoeksmethoden die eerder in dit artikel zijn besproken, zouden hiervoor geschikt kunnen worden gemaakt. Dat wil zeggen, door te kijken naar hoe onze hersenen en waarneming reageren wanneer autonomie wordt beperkt door de omgeving, krijgen we nieuw inzicht in hoe detentie invloed heeft op het psychologische mechanisme (wat doorgaans niet makkelijk met vragenlijsten kan worden vastgesteld) dat ten grondslag ligt aan zelfredzaamheid.

Onderzoek naar de rol van het brein met betrekking tot gevolgen van detentie en vrijwillig handelen staat nog in de kinderschoenen. In een van de eerste neurocognitieve studies bij gedetineerden in Nederland werd een neuropsychologische test gebruikt om executief functioneren - het plannen, uitvoeren en sturen van doelgericht gedrag - onder gedetineerden te meten. ${ }^{63}$ Executief functioneren ondersteunt het realiseren van doelen die we persoonlijk uit eigen beweging stellen en heeft als zodanig een relatie met zelfredzaamheid. Het onderzoek liet zien dat een gevange-

62 M. Liem \& N.J. Richardson, "The role of transformation narratives in desistance among released lifers', Criminal Justice and Behavior 2014, 41, p. 692-712.

63 J. Meijers e.a., 'Reduced self-control after 3 months of imprisonment; a pilot study', Frontiers in Psychology 2018, 9, 69. 
nisomgeving een negatieve invloed heeft op de test. $\mathrm{Na}$ drie maanden detentie werd een achteruitgang in executief functioneren waargenomen. Deze resultaten geven aanleiding tot verder onderzoek om vast te stellen of deze afname in executief functioneren het gevolg is van verstoringen in vrijwillig handelen. In een recent gestart project gaan we deze vraag verder bestuderen door te onderzoeken hoe vormen van vrijheidsbeperkende sancties met betrekking tot persoonlijke autonomie, zoals detentie en elektronisch toezicht, de intrinsieke ervaring van vrijwillig handelen verandert. Hierbij maken we gebruik van de inzichten uit de sociale neurowetenschappen over de wijze waarop ons brein onze doelgerichte handelingen mogelijk maakt in de sociale omgeving.

Het is belangrijk dat toekomstig neurocognitief onderzoek naar de intrinsieke ervaring van vrijwillig handelen in de context van detentie ook rekening houdt met persoonlijke factoren. Een belangrijke factor is eventuele psychiatrische problematiek van justitiabelen. De prevalentie van psychiatrische problematiek onder gedetineerden is hoog. ${ }^{64}$ De mate van controle over eigen handelingen is in verband gebracht met verschillende psychiatrische aandoeningen, waaronder schizofrenie, obsessieve compulsieve stoornis, autisme en depressie. ${ }^{65,66,67,68,69,70,71}$ Een gemeenschappelijk kenmerk van deze aandoeningen is een verhoogde sensitiviteit voor verstoringen in de ervaring van vrijwillig handelen. Het is daarom van belang om in onderzoek eventuele psychiatrische problemen mee te nemen. Wanneer bijvoorbeeld blijkt dat detentie juist bij schizofrenie de intrinsieke ervaring van vrijwillig handelen verstoort, dan geeft dat mogelijk nieuw inzicht in de wijze waarlangs detentie de zelfredzaamheid verslechtert bij gedetineerden die lijden aan schizofrenie. Eenzelfde redenering zou kunnen gelden voor andere persoonlijke factoren waarvan wordt vermoed dat ze een rol spelen bij problemen rondom zelfredzaamheid als gevolg van detentie, zoals een licht verstandelijke beperking. ${ }^{72}$

Naast persoonlijke factoren is het van belang om objectieve kenmerken van autonomie mee te wegen, zoals het regime waarin de justitiabele verkeert en de mogelijkheden tot sociaal contact. Mogelijk zal de intrinsieke ervaring van vrijwillig

64 B.H. Bulten \& H.L.I. Nijman (2009), "Veel psychiatrische stoornissen onder gedetineerden op reguliere afdelingen van penitentiaire inrichtingen', Nederlands Tijdschrift voor Geneeskunde 2009, 153, p. 634.

65 C. S. Mellor, 'First rank symptoms of schizophrenia: I. The frequency in schizophrenics on admission to hospital. II. Differences between individual first rank symptoms', British Journal of Psychiatry 1970, 117, p. 15--23.

66 R.A. Renes e.a., 'Abnormalities in the establishment of feeling of self-agency in schizophrenia', Schizophrenia Research 2013, 1, p. 50-54.

67 E. Oren, N. Friedmann \& R. Dar, 'Things happen: individuals with high obsessive-compulsive tendencies omit agency in their spoken language', Consciousciousness and Cognition 2016, 42, p. 125-134.

68 A. Gentsch e.a., 'Dysfunctional forward model mechanisms and aberrant sense of agency in obsessive-compulsive disorder', Biological psychiatry 2012, 7, p. 652-659.

69 T. Zalla \& M. Sperduti, 'The sense of agency in autism spectrum disorders: a dissociation between prospective and retrospective mechanisms?', Frontiers in Psychology 2015, 6, e1278.

70 S.S. Obhi, K.M. Swiderski \& R. Farquhar, 'Activating memories of depression alters the experience of voluntary action', Experimental Brain Research 2013, 3, p. 497-506.

71 H. Aarts, D.M. Wegner \& A. Dijksterhuis, 'On the feeling of doing: Dysphoria and the implicit modulation of authorship ascription', Behaviour Research and Therapy 2006, 11, p. 1621-1627.

72 P. Vrij \& H. Kaal, Licht verstandelijke beperking in detentie. Een handreiking voor medewerkers van DJI in de omgang met gedetineerden met een LVB, Leiden: Hogeschool Leiden 2015. 
handelen afnemen naarmate het regime strenger is en de mogelijkheden tot sociaal contact meer beperkt zijn. Ook de duur van detentie zou hierbij moeten worden meegenomen. Langdurige detentie zou de intrinsieke ervaring van vrijwillig handelen verder kunnen verstoren, wat in verband wordt gebracht met aangeleerde hulpeloosheid. ${ }^{73,74}$ In dit geval zouden gedetineerden de opgelegde regels en gedwongen routines op den duur niet meer ervaren als het ontnemen van vrijheid, maar als de nieuwe manier van leven. Deze voorgestelde relatie tussen langdurige opsluiting en verstoring in vrijwillig handelen is speculatief, maar het is goed mogelijk dat sterke ondermijning van zelfstandig functioneren voor lange tijd (ex-) gedetineerden niet meer in staat stelt om zichzelf te redden in de moderne samenleving. Een dergelijk effect kan leiden tot het hospitalisatiesyndroom. ${ }^{75}$

Een verminderde zelfredzaamheid als gevolg van detentie en de uitwerking die dit mogelijk heeft op het resocialisatieproces van gedetineerden zouden ook een rol kunnen spelen in de verhoogde recidivecijfers die in verband zijn gebracht met gevangenisstraffen ten opzichte van andere straffen, zoals werkstraffen of elektronische detentie. ${ }^{76,77,78,79}$ Ex-gedetineerden die minder zelfredzaam zijn en daarom moeite ondervinden om zich aan te passen aan de verwachtingen die in de samenleving gesteld worden, lopen mogelijk een groter risico om terug te vallen in crimineel gedrag. Het is in dit verband belangrijk om in toekomstig onderzoek te kijken naar mogelijke veranderingen in intrinsieke ervaring van vrijwillig handelen waarlangs detentie via beperkingen in autonomie resocialisatie bemoeilijkt en tot terugval kan leiden.

Samenvattend, in dit artikel is een eerste analyse gegeven over hoe de relatie tussen persoonlijke autonomie en de intrinsieke ervaring van vrijwillig handelen mogelijk de sleutel kan zijn om te begrijpen hoe vrijheidsbeperkingen in detentie de zelfredzaamheid kunnen verminderen. Hoewel uit eerder onderzoek is gebleken dat autonomie en de ervaring van vrijwillig handelen een belangrijke rol spelen in het doelgericht handelen en de zelfredzaamheid van de mens, is er tot op heden nog weinig bekend over deze relatie in de context van detentie, een context waarin autonomie overduidelijk ingeperkt is. Om meer inzicht te krijgen in de relatie tussen autonomie, de intrinsieke ervaring van vrijwillig handelen en zelfredzaamheid kan neurocognitief onderzoek worden ingezet als aanvulling op de methoden die reeds worden gebruikt en van mensen vereisen om antwoord te geven op vragen die verwijzen naar deze relatie (bijvoorbeeld via een vragenlijst of interview). Meer inzicht in de werking van het psychologische mechanisme onderliggend aan het onbedoelde negatieve effect van detentie kan op termijn mogelijk aanknopings-

73 W. Soral, M. Kofta \& M. Bukowski, 'Helplessness experience and intentional (un-) binding: Control deprivation disrupts the implicit sense of agency', Journal of Experimental Psychology: General 2020, 2, p. 289-305.

74 A. Tapal e.a., 'The sense of agency scale: A measure of consciously perceived control over one's mind, body, and the immediate environment', Frontiers in Psychology 2017, 8, p. 1552.

75 E. Goffman, Asylums. Essays on the mental patients and on the inmates, New York: Doubleday.

76 Nagin, Cullen \& Jonson 2009, p. 115-200.

77 Jonson 2010.

78 Villettaz, Gillieron \& Killias 2015, p. 1-92.

79 H. Wermink e.a., 'Recidive na werkstraffen en na gevangenisstraffen', Tijdschrift voor Criminologie 2009, 51, p. 211-227. 
punten opleveren voor nieuwe interventies binnen detentie waarin meer gefocust wordt op het bevorderen van de zelfredzaamheid. 